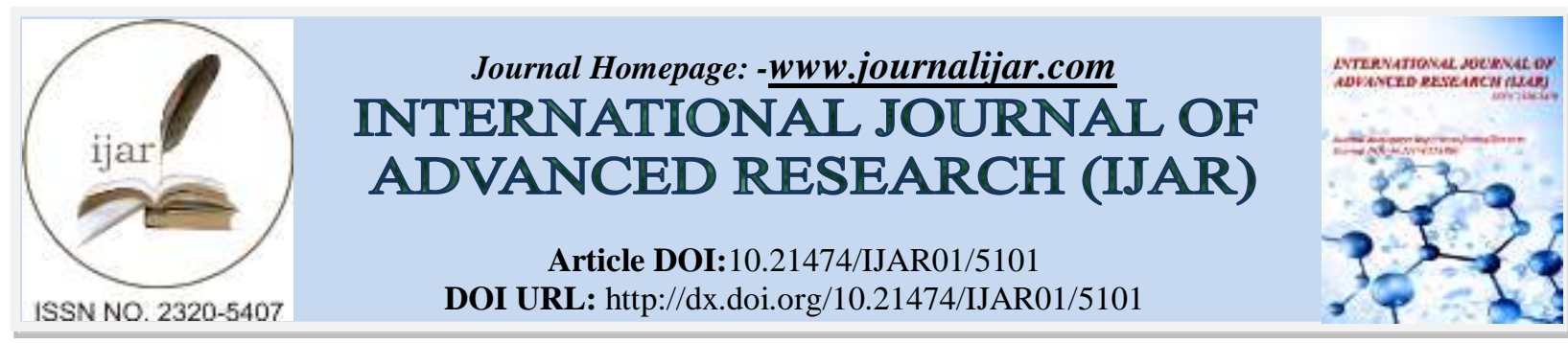

RESEARCH ARTICLE

\title{
VISUAL INTERPRETATION METHODS OF LAND USE/LAND COVER CHANGES \& ANALYSIS USING GIS \& REMOTE SENSING TECHNOLOGY: A CASE STUDY OF GOMUKHI RIVER BASIN OF TAMILNADU, INDIA.
}

\section{V.Govindaraj, C.Lakshumanan and P.Ramki.}

Centre for Remote Sensing, Bharathidasan University, Tiruchirappalli- 620023.

\section{Manuscript Info}

Manuscript History

Received: 08 June 2017

Final Accepted: 10 July 2017

Published: August 2017

Key words:-

land use /land cover changes, GIS, visual interpretation, Remote sensing.

\begin{abstract}
The proper watershed or river basin development of a management strategy requires accurate measurement of the past and present land use/land cover changes of study area. These land use/land cover parameters determine the hydrological and ecological processes taking place in with a watershed area. This study done by satellite image of Landsat -7ETM+ in 2006, 2010, 2016 using Arc GIS 10.1 software and update the year of 2016image is using Geo Eye data. The Gomukhi river basin classified into NRSC level-2 land use /land cover classes Viz. crop land, fallow land, plantation, dense forest, open forest ,degraded forest, land with scrub, land without scrub, rivers/lakes(water bodies), settlement(Built Up land), and barren rocky. The overall analysis of study area the years of 2006 to 2016 land use land cover classes of viz., crop land (11.95\%), plantation (1.57\%) and dense forest $(0.09 \%)$ is decreasing. And also fallow land $(9.64 \%)$, open forest $(0.47 \%)$, degraded forest $(0.70 \%)$, land with scrub (1.41\%), land without scrub $(0.86 \%)$, rivers/lakes $(0.15 \%$ and settlement $(1.48 \%)$ respectively, barren rocky no changes accruing the study area. The land use /land cover classes transformation posed a serious threat to river basin or watershed resources. Here proper river basin planning and management is required or else these land use /land cover resources will soon be lost and no longer be able to play their role in socio economic based sustainable development of the study area.
\end{abstract}

Copy Right, IJAR, 2017,. All rights reserved.

\section{Introduction:-}

Land Use Land Cover dynamics serves as a crucial parameter in current strategies and policies for natural resource management and monitoring. Currently, the world has witnessed the importance of land use /land cover changes in world-wide environmental modifications that can lead to adverse effects (Iqbal and Khan, 2014). The Changes in land use /land cover signify environmental changes brought about by natural or anthropogenic consequences (Rawat and Kumar, 2015). This provides an important aspect in evaluating, monitoring and conserving Earth's resources that is required for sustainable development and economic proliferation of an area (Rawat et al., 2013a). Changes in the land use/land cover in a watershed can affect water quality and supply. For instance, land use/land cover patterns change due to watershed development frequently resulting in increased surface runoff, reduced groundwater recharge and transfer of pollutants (Turner et al., 2001). Thus, the assessment of land use/land cover patterns and their changes at the watershed level is crucial to planning and management of water resources and land use/land 
cover of the particular watershed. Various studies have been conducted all over the world regarding the change analysis of watersheds through different methods. They are important to develop effective management strategies for watersheds worldwide (Ashraf, 2013; Bazgeera et al., 2008; Caruso et al., 2005; Dietzel et al., 2005; Fortin et al., 2003; Gajbhiye and Sharma, 2012; Hu et al., 2012; Kearns et al., 2005; Parker and Meretsky, 2004; Stewart et al., 2004; Wang et al., 2004). Watershed management is necessary because a watershed is not merely a hydrological unit (Singh et al., 2014) but also socio-ecological being which plays a vital role in determining economical, food and social security and provision of life support services to local residents (Wani et al., 2008). Changes in land use/land cover inwatershed. The area including urbanization and de forestation continuously affect the water availability as well as the nature and extent of surface and subsurface water interactions thus influencing watershed ecosystems and the services provided by them. With proper understanding of the spatial and temporal variations occurring in a watershed over time and the interaction of the hydrological components of a watershed with each other, better water conservation strategies can be formulated (Ashraf, 2013). The land use and land cover analysis is use of Remote Sensing, and Geographic Information Systems, the enumeration of spatial-temporal land use/ land cover dynamics has become easy, quick, Cost-effective and accurate (Rawat and Kumar, 2015).Similar technique was used to changes observed in a nearby watershed (Rawal watershed, Islamabad, Pakistan) and achieved up to $95 \%$ accurateresults (Butt et al., 2015). Several other researchers have employed the same technique and achieved highly satisfactory results including (Rawat and Kumar (2015), who applied the same technique to monitor land use/land cover change in Hawalbagh block, district Almora, Uttarakhand, India. Boori et al. (2015) analyzed the land use/land cover disturbance caused by tourism using a number of Remote Sensing and GIS based techniques including supervised classification.(Rawat et al. (2013) also applied the same technique for Ramnagar town area, Uttarakhand, India to track the changes observed in the area between the time period of 1990 and $2010 . \quad$ The Gomukhi river basin was selected for land use /land cover changes is being subjected to urbanization, sewage discharges without treatment, active water and soil erosion, over grazing, cutting of trees, non-existence of any cooperative communal structure and reduced livelihood opportunities. Along with these, rapid discharge of pesticide residues and poultry discharge in the streams is also one of the major concerns faced by the Gomukhi river basin due to the rapidly increasing agricultural activities and number of poultry farms in the study area.. The rapid urban development taking place in the study area has led to environmental problems as well, encompassing, fragmentation of aquatic habitats, soil erosion, and water pollution due to deforestation and discharge of municipal garbage and industrial waste (HaglerBailly, 2007; Tanvir et al., 2006). Therefore, the main objective of the present research was to utilize GIS applications to discern the extent of changes occurred inGomukhi river basin villupuram district of tamilnadu, 2006 to 2016 time period.

\section{Objectives of study:-}

1. To identify and delineate different land use /land cover categories and pattern of land use change in Gomukhi river basin from 2006 to 2016

2. To examine the potential of integrating GIS with RS in studying the spatial distribution of different land use /land cover changes in years of 2006,2010, and 2016

\section{Study Area:-}

The Gomukhi river basin located in semi-arid tropical climate region of north side of Vilupuram District, southern side ofSalem district, western side of Dharmapuri district, northern western side ofTirvannamalai district and eastern side is cuddaloredistrict .The extend Between coordinates of from $11^{\circ} 31^{\prime} 40.7^{\prime}{ }^{\prime} \mathrm{N}$ to $11^{\circ} 51^{\prime} 53.185^{\prime} \mathrm{N}$ and $78^{\circ} 36^{\prime} 44.894^{\prime \prime} \mathrm{E}$ to $79^{\circ} 7^{\prime} 45.337^{\prime \prime} \mathrm{E}$. The River basin covered in total area of $1122.67 \mathrm{~km}^{2}$, out of $851.15 \mathrm{~km}^{2}$ is Villupuram district, $146.22 \mathrm{~km}^{2}$ Cuddalore district and $125.30 \mathrm{~km}^{2}$ is Salem district respectively. The population is 4, 52443 out of 2, 28385 male population and 2, 24058 female population and population density is 403 for per sq.km in census of India for 2011data. The survey of India Toposheet(1:50000) no is 58I/9, 58I/10, 58I/13 and 58I/14. This study area covering the tropical deciduous forest type of the reserved forest isviz,MagarurR.F(6.96km²),PorasakkurichchiR.F.(3.03 km²),PusappadiR.F.(6.35 $\left.\mathrm{km}^{2}\right)$,TakaraiR.F.(45.65km²),Varanj aramR.F.(3.104km²),KrishnapuramR.F.(25.09km²),KottalammalaiR.F.(11.43km²),KattumayilurR.F.(6.108km²),andJ adayakavundanslopesR.F. $\left(23.25 \mathrm{~km}^{2}\right)$, and also the whole are is fairly smooth, with soil well-suited for plant growth. Scrub jungles reach up to 400 metres in altitude, while deciduous forests can be found between above 800 metres. Sholas, a type of high-altitude stunted evergreen forest, can be found growing on isolated plateaus. This basin are 163(36.22 $\left.\mathrm{km}^{2}\right)$ manmade and natural water bodies (Lakes)founded and one reservoir of Gomukhi $\operatorname{dam}(709.29$ Acres ) built in year of 1965, in the valley of the river basin .It is about $16 \mathrm{~km}$ north-west of Kallakurichi. Its area covering 10,800 acres during normal monsoon season .The national high way -79 crossing the north to south western side direction of centre of basin this could be majorroad connection of other district. The 
Gomukhi River stream are flowing is west to east direction of the study area and major catchment is north western side of the Kalrayan hills. His Kalrayan Hills are a major range of hills situated in the Eastern Ghats of the southern Indian state of Tamil Nadu.The hills range in height from 609.6 Metre to 914.4 metreand extend over an area of 1095 sq.km. The study area covering the kalrayan hills is 369.5 Sq.km and highest elevation point observed in nearby the area of kallur village (1257M, 1298M) of north western region.along with the Pachaimalai, Javadi, and Shevaroy hills, they separate the Kaveri River basin to the south from the Palar River basin to the north. There are Gomukhi river is two main tributaries is including, Mayuranadi, Tirumanimuktanadi,of right bank and alsoGomukhi river is tributaries of Vellar river basin of left bank (Fig1.2).

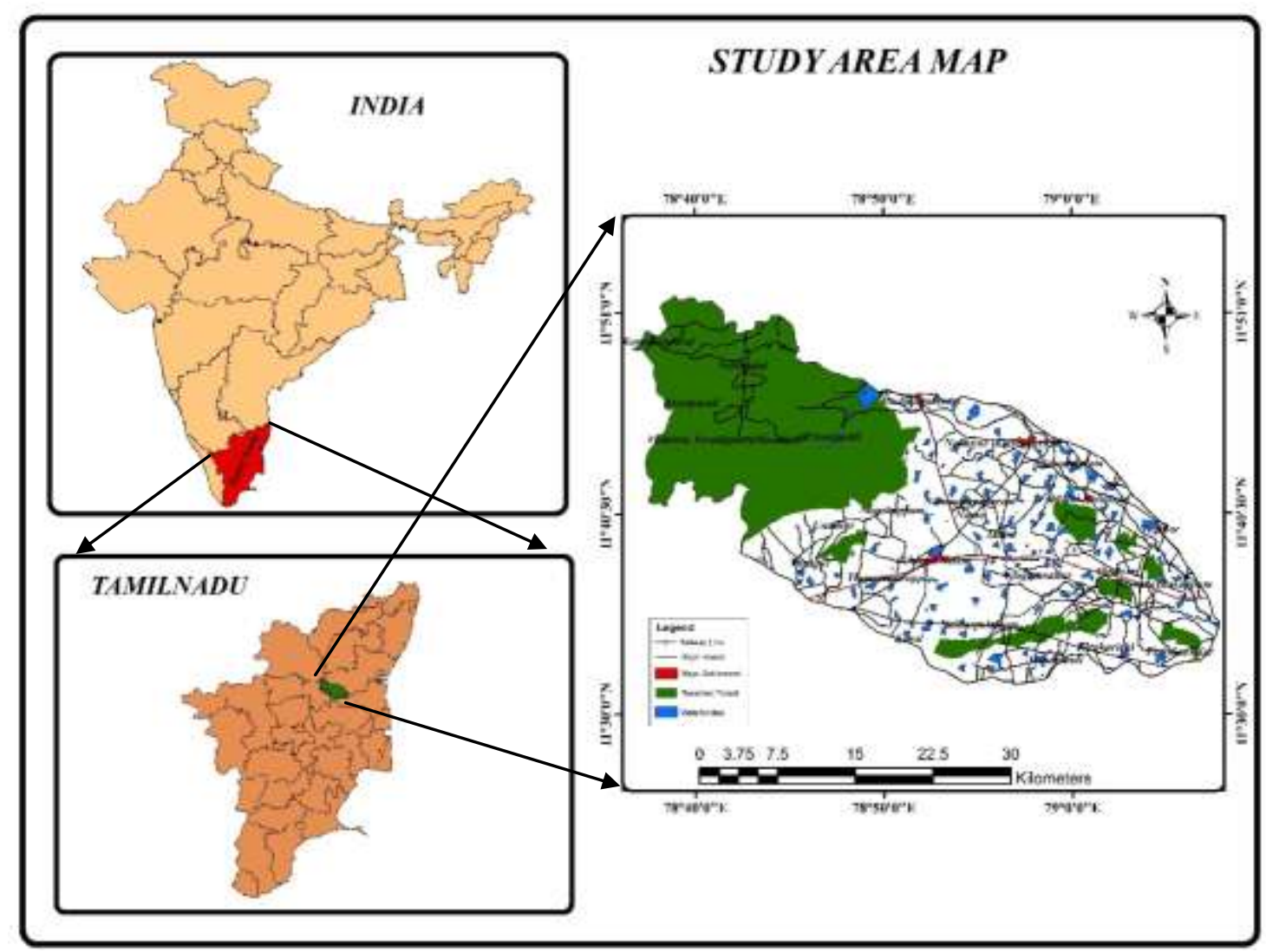

Fig-1.2:- Location Map of the Study Area

\section{Materials and methods:-}

\section{Methodology:-}

The base maps of were extracting from Survey of India (SOI) Topographic maps on a 1:50,000 scale (Fig-2.1). The Study area is covering Toposheets no. 58I/9, 58I/10, 58I/13 and 58I/14. The satellite data Landsat 7 ETM+ spatial resolution 30M downloaded from U.S. Geological Survey department. The years of 21-jan-2006, 9-Feb-2010.The Geo eye satellite data downloaded from Google Earth year of Feb-2016. These data sets were imported in ERDAS Imagine version 9.3 (LeicaGeosystems, Atlanta, U.S.A.), satellite image processing software to create a false colour composite. The layer stack option in image interpreter tool box was used to generate FCCs for the study areas. The sub-setting of satellite images were performed for extracting study area from both images by taking geo-referenced out line boundary of Gomukhi river basin as AOI (Area of Interest). This satellite data used visual interoperation methods according to the NRSC level -2 classification using ArcGIS 10.1 platform. 


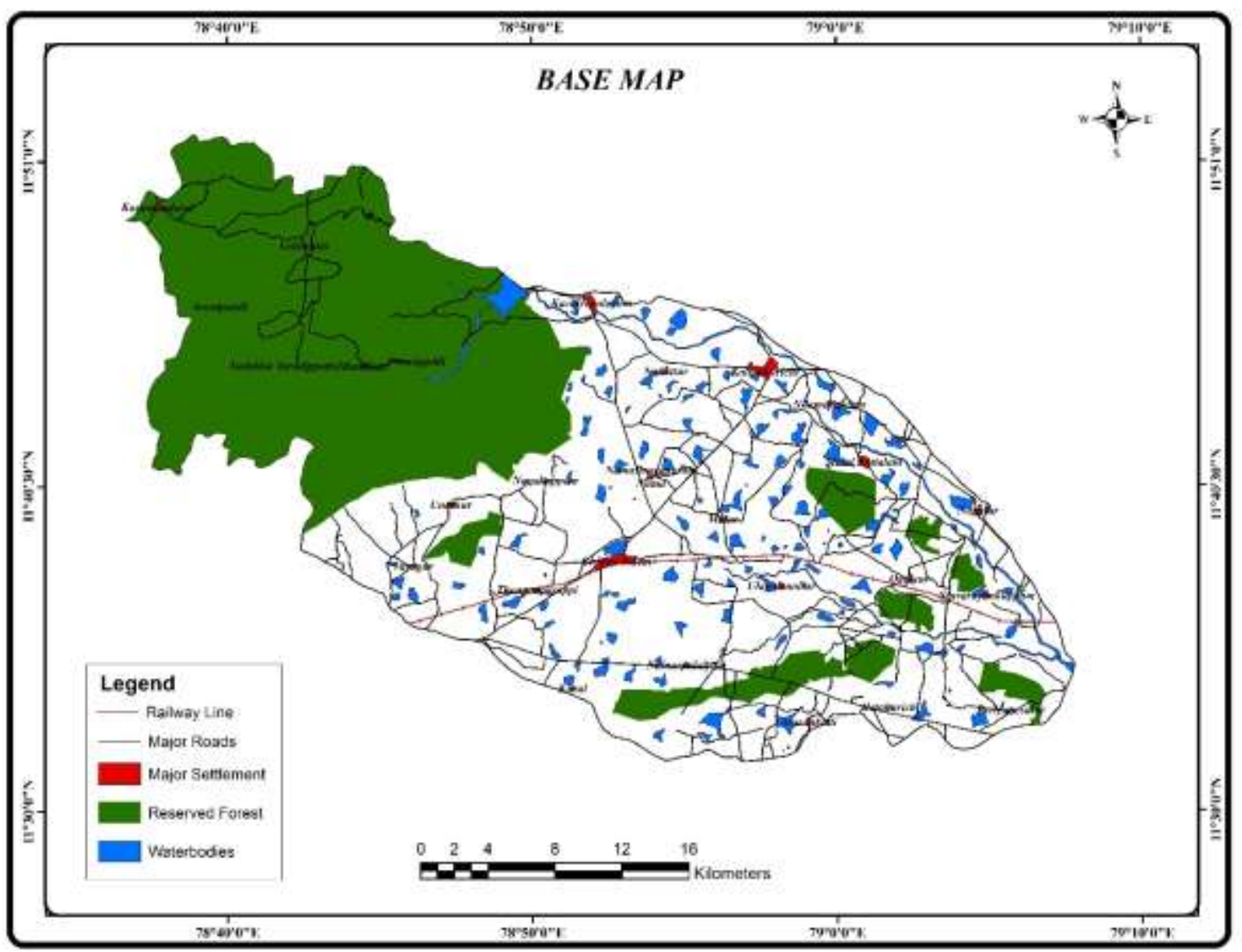

\section{Results and discussion:-}

Fig-2.1:- Base Map of Study Area

\section{Land use/Land cover:-}

The Land use/ Land cover study area has been attempted in order to identify and map the various types of land use/ land cover classes in the area by visual interpretation. The Land use classification of the specified area using remotely sensed data. Land use is obviously constrained by environmental factors such as soil characteristics, climate, topography and vegetation. But, it also reflects the land as a key and finite resource for most human activities including agriculture, industry, forestry, energy, production, settlement, recreation and water catchments and storage. The Land use of the area has been classified based on NRSC LEVEL II land use land cover classification as shown (Table 3.1)

\begin{tabular}{|c|c|c|c|}
\hline Sl. & Description-1 & Description-2 & Description-3 \\
\hline \multirow[t]{3}{*}{1} & \multirow[t]{3}{*}{ Built-up } & Urban & $\begin{array}{l}\text { Residential, Mixed built up, Public / Semi Public, } \\
\text { Communication, Public utilities / facility, Commercial, } \\
\text { Transportation, Reclaimed land, Vegetated Area, } \\
\text { Recreational, Industrial, Industrial / Mine dump, Ash / } \\
\text { Cooling pond }\end{array}$ \\
\hline & & Rural & Rural \\
\hline & & Mining & Mine / Quarry, Abandoned Mine Pit, Land fill area \\
\hline \multirow{5}{*}{2} & \multirow{4}{*}{ Agriculture } & Crop land & Kharif, Rabi, Zaid, Two cropped, More than two cropped \\
\hline & & Plantation & Plantation - Agricultural, Horticultural, Agro Horticultural \\
\hline & & Fallow & Current and Long Fallow \\
\hline & & $\begin{array}{ll}\begin{array}{l}\text { Current } \\
\text { cultivation }\end{array} & \text { Shifting } \\
\end{array}$ & Current Shifting cultivation \\
\hline & & $\begin{array}{lll}\begin{array}{l}\text { Evergreen } \\
\text { evergreen }\end{array} & / & \text { Semi } \\
\end{array}$ & $\begin{array}{l}\text { Dense /Closed and Open category of Evergreen / Semi } \\
\text { evergreen }\end{array}$ \\
\hline
\end{tabular}




\begin{tabular}{|c|c|c|c|}
\hline \multirow[t]{4}{*}{3} & \multirow[t]{4}{*}{ Forest } & Deciduous & $\begin{array}{l}\text { Dense / Closed and Open category of Deciduous and Tree } \\
\text { Clad Area }\end{array}$ \\
\hline & & Forest Plantation & Forest Plantation \\
\hline & & Scrub Forest & $\begin{array}{l}\text { Scrub Forest, Forest Blank, Current \& Abandoned Shifting } \\
\text { Cultivation }\end{array}$ \\
\hline & & Swamp / Mangroves & Dense / Closed \& Open Mangrove \\
\hline 4 & Grass/ Grazing & Grass/ Grazing & $\begin{array}{l}\text { Grassland: Alpine / Sub-Alpine, Temperate / Sub Tropical, } \\
\text { Tropical / Desertic }\end{array}$ \\
\hline \multirow[t]{6}{*}{5} & \multirow{6}{*}{$\begin{array}{l}\text { Barren } \\
\text { /uncultivable } \\
\text { /Wastelands }\end{array}$} & Salt Affected Land & Slight, Moderate \& Strong Salt Affected Land \\
\hline & & Gullied / Ravinous Land & Gullied, Shallow ravine \& Deep ravine area \\
\hline & & Scrub land & Dense / Closed and Open category of scrub land \\
\hline & & Sandy area & Desertic, Coastal, Riverine sandy area \\
\hline & & Barren rocky & Barren rocky \\
\hline & & Rann & Rann \\
\hline \multirow{4}{*}{6} & \multirow{4}{*}{$\begin{array}{l}\text { Wetlands } \\
\text { Water Bodies }\end{array}$} & Inland Wetland & Inland Natural and Inland Manmade wetland \\
\hline & & Coastal Wetland & Coastal Natural and Coastal Manmade wetland \\
\hline & & River / Stream / canals & Perennial \& Dry River/stream and line \& unlined canal/drain \\
\hline & & Water bodies & $\begin{array}{l}\text { Perennial, Dry, Kharif, Rabi \&Zaid extent of lake/pond and } \\
\text { reservoir and tanks }\end{array}$ \\
\hline 7 & $\begin{array}{l}\text { Snow } \\
\text { Glacier }\end{array}$ & & Seasonal and Permanent snow \\
\hline
\end{tabular}

Table-3.1:- NRSC Land Use and Land Cover Classes

\section{Urban Settlement:-}

Urban areas are non-linear built up areas covered by impervious structures adjacent to or connected by streets. This cover is related to canters of population. This class usually occurs in combination with, vegetated areas that are connected to buildings that show a regular pattern, such as vegetated areas, gardens etc. and industrial and/or other areas. (FAO, 2005).It includes residential areas, mixed built-up, recreational places, public / semi-public utilities, communications, public utilizes/facility, commercial areas, reclaimed areas, vegetated areas, transportation, industrial areas and their dumps, and ash/cooling ponds.

\section{Rural Settlement:-}

These are the lands used for human settlement of size comparatively less than the urbansettlements of which the majority of population is involved in the primary activity of agriculture.These are the built-up areas, smaller in size, mainly associated with agriculture and allied sectorsand non-commercial activities. They can be seen in clusters non- contiguous or scattered.

\section{Cropland:-}

These are the areas with standing crop as on the date of Satellite overpass. Cropped areas appear in bright red to red in color with varying shape and size in a contiguous to non-contiguous pattern. They are widely distributed indifferent terrains; prominently appear in the irrigated are as irrespective of the source of irrigation. It includes kharif, rabi and zaid crop lands along with areas under double or triple crops.

\section{Plantations:-}

These are the areas under agricultural tree crops planted adopting agricultural management techniques. Depending on the location, they are exhibit a dispersed or contiguous pattern. Use of multi-season data will enable their separation in a better way. It includes agricultural plantation (like tea, coffee, rubber etc.) horticultural plantation (like coconut, arecanut, citrus fruits, orchards, fruits, ornamental shrubs and trees, vegetable gardens etc) and agrohorticultural plantation.

\section{Fallow:-}

An agricultural system with an alternation between a cropping period of severalyears and a fallow period.(Ruthenberg, 1980). In another terms these are the lands, which aretaken up for cultivation but are temporarily allowed to rest, un-cropped for one or more season,but not less than one year. 


\section{River /lakes:-}

Rivers/streams are natural course of water flowing on the landsurface along a definite channel/slope regularly or intermittently towards a sea in most cases orin to a lake or an inland basin in desert areas or a marsh or another river.

\section{Water Bodies:-}

This category comprises areas with surface water in the form of ponds, lakes, tanks and reservoirs.

\section{Scrub Land:-}

Scrub Land these areas possess shallow and skeletal soils, at times degraded, extremes of slopes, severely eroded and lands subjected to excessive aridity with scrubs dominating the landscape. They have a tendency for intermixing with cropped areas. They appear in light yellow to brown to greenish blue depending on the surface moisture cover and vary in size from small to large having either contiguous or dispersed pattern. The vegetal cover on scrub lands may be dense or sparse.

\section{Barren Rocky:-}

Barren/Rocky/Stony Waste These are rock exposures of varying lithology often barren and devoid of soil and vegetation cover. They occur amidst hill-forests as openings or as isolated exposures on plateau and plains. Such lands can be easily discriminated from other categories of wastelands because of their characteristic spectral response. They appear in greenish blue to yellow to brownish in color depending on the rock type. They vary in size with irregular to discontinuous shape with a linear to contiguous or dispersed pattern. They are located in steep isolated hillocks/hill slopes, crests, plateau and eroded plains associated with barren and exposed rocky/stony wastes, lateritic out-crops, mining and quarrying sites. These areas appear in light gray to black tone due to hill shadow on one side and light red on the other side due to vegetation, the tonal variation is subject to degree of soil erosion.

\section{Forest:-}

The term forest is used to refer to land with a tree canopy cover of more than 10 percent and area of more than 0.5 ha. Forests are determined both by the presence of trees and the absence of other predominant land uses. The trees should be able to reach a minimum height of $5 \mathrm{~m}$ (MOEF, 2011). It consists of:

\section{Evergreen/Semi-Evergreen:-}

This term as such describes the phenology of perennial plants that are never entirely without green foliage (Ford-Robertson, 1971). This category comprises of tall trees, which are predominantly remain green throughout the year. It includes both coniferous and tropical broadleaved evergreen species. Semi- evergreen is a forest type that includes a combination of evergreen and deciduous species with the former dominating the canopy cover.

\section{Deciduous:-}

This applies to the phenology of perennial plants that are leafless for a certain period of the year (Ford-Robertson, 1971). The leaf shedding usually takes place simultaneously in connection with the unfavourable season (UNESCO, 1973). These are the forest types that are predominantly composed of species, which shed their leaves once a year, especially during summer. It also includes tree clad area with tree cover lying outside the notified forest boundary areas that are herbaceous with a woody appearance (e.g. bamboos, palms, tree ferns etc.).

\section{Degraded Forest:-}

Degraded Forest land Lands within Notified Forest boundaries, with various types of forest cover, in which vegetative cover is less than $20 \%$ are classified as degraded / underutilised. These lands are generally confined to the fringe areas. Such lands appear in dark gray to light red tone during the maximum green period. The tonal variations are subject to change with the foliage cover and the season of data acquisition. 


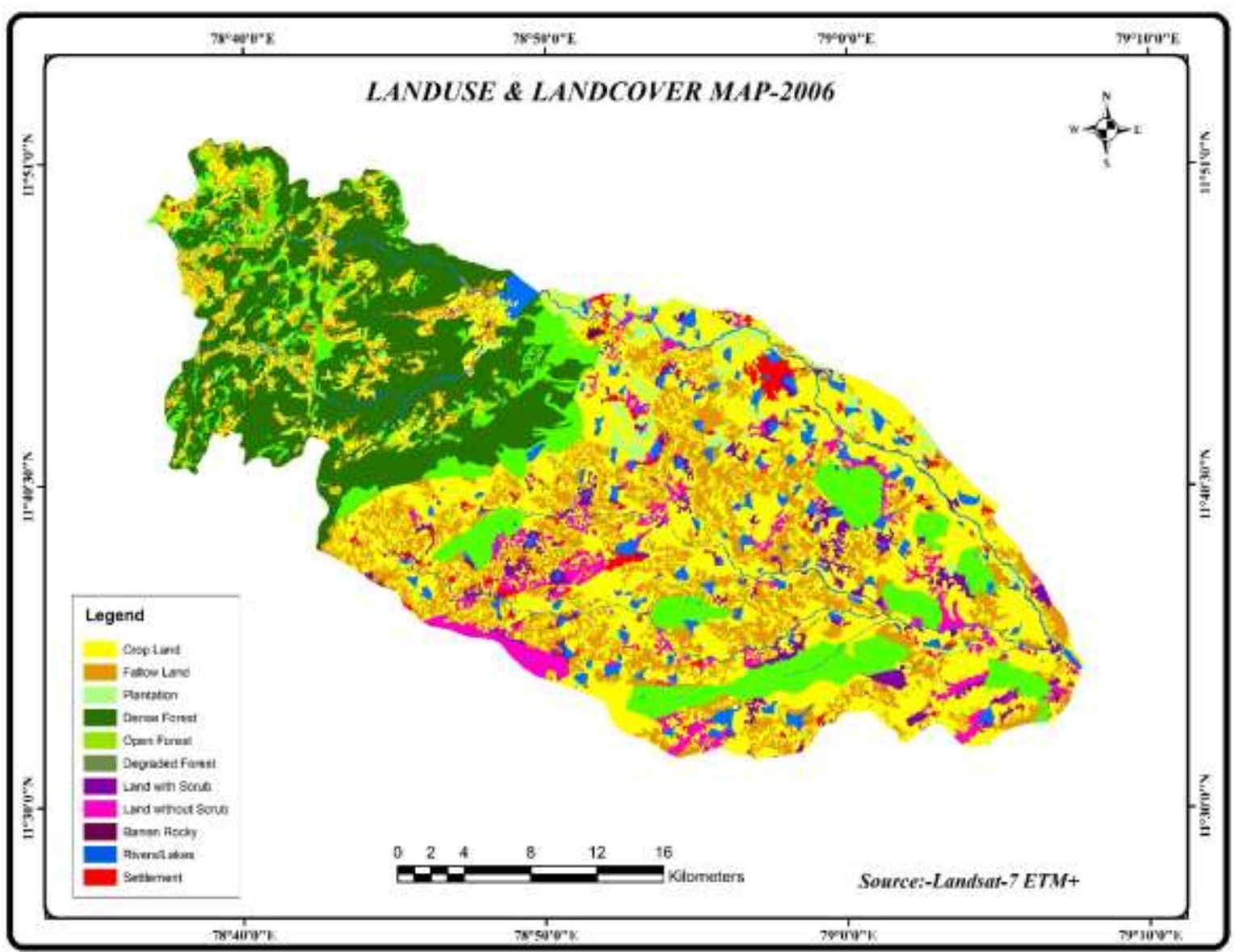

Fig-3.1:- Land use/Land cover Map-2006

\begin{tabular}{|l|l|l|l|}
\hline S.no & Land use/Land cover Classes & Area in Sq.km & Area in \% \\
\hline 1 & Crop land & 406.40 & 36.19 \\
\hline 2 & Fallow land & 181.22 & 16.14 \\
\hline 3 & Plantation & 22.86 & 2.04 \\
\hline 4 & Dense Forest & 223.33 & 19.89 \\
\hline 5 & Open Forest & 134.04 & 11.94 \\
\hline 6 & Degraded Forest & 2.39 & 0.21 \\
\hline 7 & Land with Scrub & 31.71 & 2.82 \\
\hline 8 & Land without Scrub & 47.80 & 4.26 \\
\hline 9 & Barren Rocky & 0.45 & 0.04 \\
\hline 10 & Rivers \& Lakes & 56.38 & 5.02 \\
\hline 11 & Settlement & 16.34 & 1.45 \\
\hline $\mathbf{1 2}$ & Total & $\mathbf{1 1 2 2 . 9 2}$ & $\mathbf{1 0 0 . 0 0}$ \\
\hline
\end{tabular}

Table-3.1:- Distribution of Land use \&Landcover-2006 


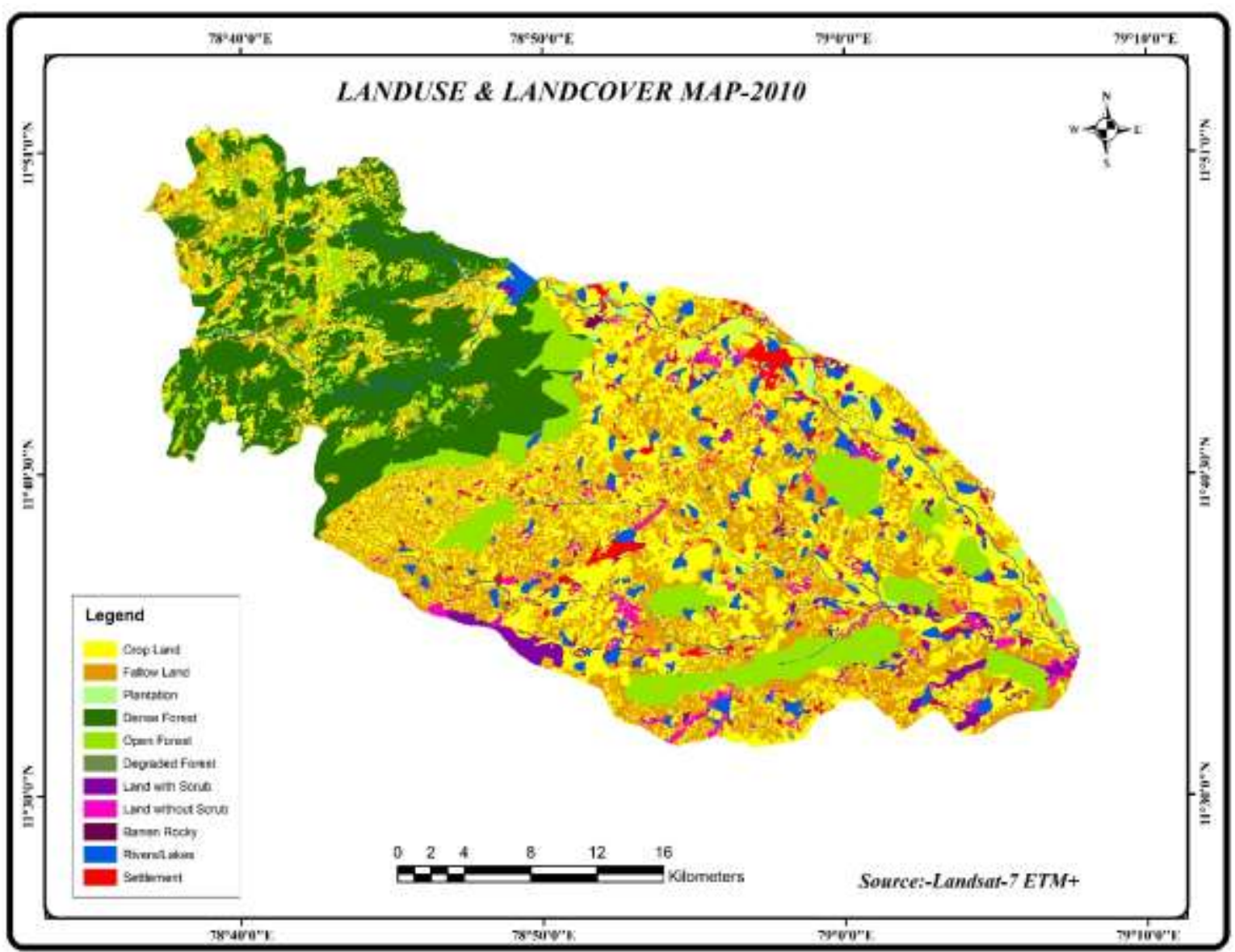

Fig-3.2:- Land use/Land cover Map-2010

\begin{tabular}{|l|l|l|l|}
\hline S.no & Land use/Land cover Classes & Area in Sq.km & Area in \% \\
\hline 1 & Crop land & 366.11 & 32.63 \\
\hline 2 & Fallow land & 266.90 & 23.79 \\
\hline 3 & Plantation & 11.31 & 1.01 \\
\hline 4 & Dense Forest & 210.69 & 18.78 \\
\hline 5 & Open Forest & 132.89 & 11.84 \\
\hline 6 & Degraded Forest & 5.13 & 0.46 \\
\hline 7 & Land with Scrub & 25.90 & 2.31 \\
\hline 8 & Land without Scrub & 29.12 & 2.60 \\
\hline 9 & Barren Rocky & 0.39 & 0.03 \\
\hline 10 & Rivers \& Lakes & 53.06 & 4.73 \\
\hline 11 & Settlement & 20.53 & 1.83 \\
\hline $\mathbf{1 2}$ & Total & $\mathbf{1 1 2 2 . 0 2}$ & $\mathbf{1 0 0 . 0 0}$ \\
\hline
\end{tabular}

Table-3.2:- Distribution of Land use \&Landcover-2010 


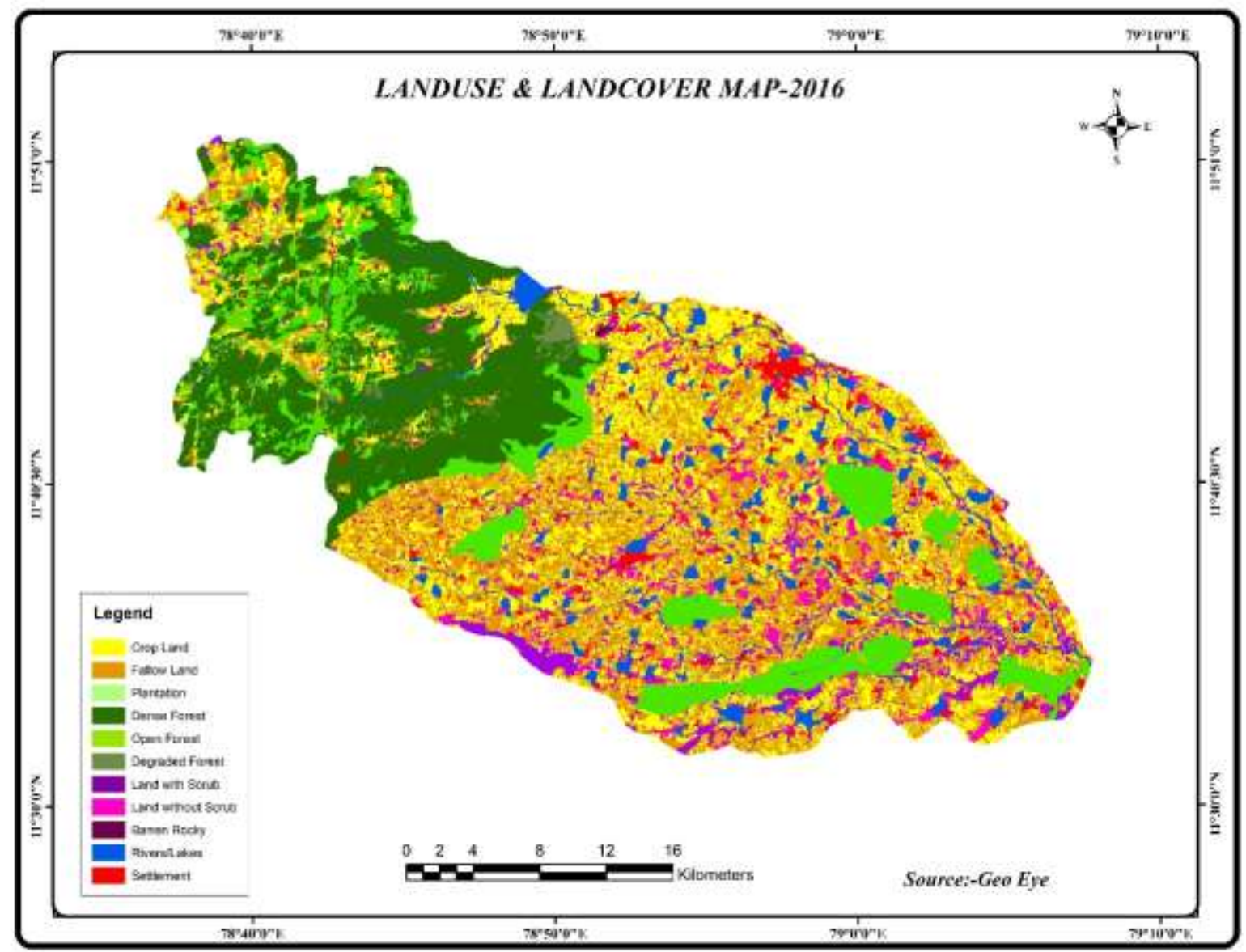

Fig-3.3:- Land use/Land cover Map-2016

\begin{tabular}{|l|l|l|l|}
\hline S.no & Land use/Land cover Classes & Area in Sq.km & Area in \% \\
\hline 1 & Crop land & 272.11 & 24.24 \\
\hline 2 & Fallow land & 289.36 & 25.78 \\
\hline 3 & Plantation & 5.28 & 0.47 \\
\hline 4 & Dense Forest & 209.79 & 18.69 \\
\hline 5 & Open Forest & 139.21 & 12.40 \\
\hline 6 & Degraded Forest & 10.29 & 0.92 \\
\hline 7 & Land with Scrub & 47.52 & 4.23 \\
\hline 8 & Land without Scrub & 57.47 & 5.12 \\
\hline 9 & Barren Rocky & 0.46 & 0.04 \\
\hline 10 & Rivers \& Lakes & 58.01 & 5.17 \\
\hline 11 & Settlement & 32.92 & 2.93 \\
\hline $\mathbf{1 2}$ & Total & 1122.39 & 100.00 \\
\hline
\end{tabular}

Table-3.3:- Distribution of Land use \&Landcover-2016

\begin{tabular}{|c|c|c|c|c|c|c|c|c|c|c|}
\hline \multirow[t]{2}{*}{ S.no } & \multirow[t]{2}{*}{ Land use classes } & \multicolumn{3}{|c|}{ Area in Sq.km } & \multicolumn{3}{|c|}{ Area in Percentage (\%) } & \multicolumn{3}{|c|}{$\begin{array}{l}\text { Changes in Percentage } \\
(\%)\end{array}$} \\
\hline & & 2006 & 2010 & 2016 & 2006 & 2010 & 2016 & 2006 & 2010 & 2016 \\
\hline 1 & Crop land & 406.40 & 366.11 & 272.11 & 36.19 & 32.63 & 24.24 & -3.56 & -8.39 & -11.95 \\
\hline 2 & Fallow land & 181.22 & 266.90 & 289.36 & 16.14 & 23.79 & 25.78 & 7.65 & 1.99 & 9.64 \\
\hline 3 & Plantation & 22.86 & 11.31 & 5.28 & 2.04 & 1.01 & 0.47 & -1.03 & -0.54 & -1.57 \\
\hline 4 & Dense Forest & 223.33 & 210.69 & 209.79 & 19.89 & 18.78 & 18.69 & -1.11 & -0.09 & -1.20 \\
\hline
\end{tabular}




\begin{tabular}{|l|l|l|l|l|l|l|l|l|l|l|}
\hline 5 & Open Forest & 134.04 & 132.89 & 139.21 & 11.94 & 11.84 & 12.40 & -0.09 & 0.56 & 0.47 \\
\hline 6 & Degraded Forest & 2.39 & 5.13 & 10.29 & 0.21 & 0.46 & 0.92 & 0.24 & 0.46 & 0.70 \\
\hline 7 & Land with Scrub & 31.71 & 25.90 & 47.52 & 2.82 & 2.31 & 4.23 & -0.52 & 1.93 & 1.41 \\
\hline 8 & $\begin{array}{l}\text { Land without } \\
\text { Scrub }\end{array}$ & 47.80 & 29.12 & 57.47 & 4.26 & 2.60 & 5.12 & -1.66 & 2.52 & 0.86 \\
\hline 9 & Barren Rocky & 0.45 & 0.39 & 0.46 & 0.04 & 0.03 & 0.04 & -0.01 & 0.01 & 0.00 \\
\hline 10 & Rivers \& Lakes & 56.38 & 53.06 & 58.01 & 5.02 & 4.73 & 5.17 & -0.29 & 0.44 & 0.15 \\
\hline 11 & Settlement & 16.34 & 20.53 & 32.92 & 1.45 & 1.83 & 2.93 & 0.38 & 1.10 & 1.48 \\
\hline 12 & Total & $\mathbf{1 1 2 2 . 9 2}$ & $\mathbf{1 1 2 2 . 0 2}$ & $\mathbf{1 1 2 2 . 3 9}$ & $\mathbf{1 0 0 . 0 0}$ & $\mathbf{1 0 0 . 0 0}$ & $\mathbf{1 0 0 . 0 0}$ & & & \\
\hline
\end{tabular}

Table-3.4:- Land use \& Land cover Changes-2006 to 2016

Land use and land cover changes in 2006 to 2016:-

Land use/land cover assessment based on interpretation of satellite data of 2006,2010 ,and 2016 indicate land use categories viz., cropland, fallow land, plantation, dense forest,openforest,degradedforest,landwithscrub,landwithoutscrub, barrenrocky,rivers\&lakes,settlement.The Gomukhi river basin dominant use of categories in 2006are:crop land $\left(406.40 \mathrm{~km}^{2}\right)$, fallow land $\left(181.22 \mathrm{~km}^{2}\right)$,plantation $(22.862)$, dense forest $\left(223.33 \mathrm{~km}^{2}\right)$ open forest $\left(134.04 \mathrm{~km}^{2}\right)$, degraded forest $\left(2.39 \mathrm{~km}^{2}\right)$ land with scrub $\left(31.71 \mathrm{~km}^{2}\right)$, land without scrub $\left(47.80 \mathrm{~km}^{2}\right)$ barren rocky $\left(0.54 \mathrm{~km}^{2}\right)$,rivers/lakes $\left(56.38 \mathrm{~km}^{2}\right)$,settlement(16.342).(Fig3.1),(Table-3.1).In the year of 2010 data shows crop land $\left(366.11 \mathrm{~km}^{2}\right)$, fallow land $\left(266.90 \mathrm{~km}^{2}\right)$, plantation $\left(11.31 \mathrm{~km}^{2}\right)$, dense forest $\left(210.69 \mathrm{~km}^{2}\right)$ open forest $\left(132.89 \mathrm{~km}^{2}\right)$,degraded forest $\left(5.13 \mathrm{~km}^{2}\right)$ land with scrub $\left(25.90 \mathrm{~km}^{2}\right)$, land without scrub $\left(29.12 \mathrm{~km}^{2}\right)$ barren rocky $\left(0.39 \mathrm{~km}^{2}\right)$,rivers/lakes $(53.06$ $\mathrm{km}^{2}$ ), settlement(20.53 km²).(Fig-3.2)(,Table-3.2).

In the year of 2016 data shows crop land $\left(272.11 \mathrm{~km}^{2}\right)$, fallow land $\left(289.36 \mathrm{~km}^{2}\right)$,plantation $\left(5.28 \mathrm{~km}^{2}\right)$, dense forest $\left(209.79 \mathrm{~km}^{2}\right)$ open forest $\left(139.21 \mathrm{~km}^{2}\right)$, degraded forest $\left(10.29 \mathrm{~km}^{2}\right)$ land with scrub $\left(47.52 \mathrm{~km}^{2}\right)$, land without scrub $\left(57.47 \mathrm{~km}^{2}\right)$ barren rocky $\left(0.46 \mathrm{~km}^{2}\right)$,rivers/lakes $\left(58.01 \mathrm{~km}^{2}\right)$,settlement $\left(32.92 \mathrm{~km}^{2}\right)$.(Fig-3.3),Table-3.3).

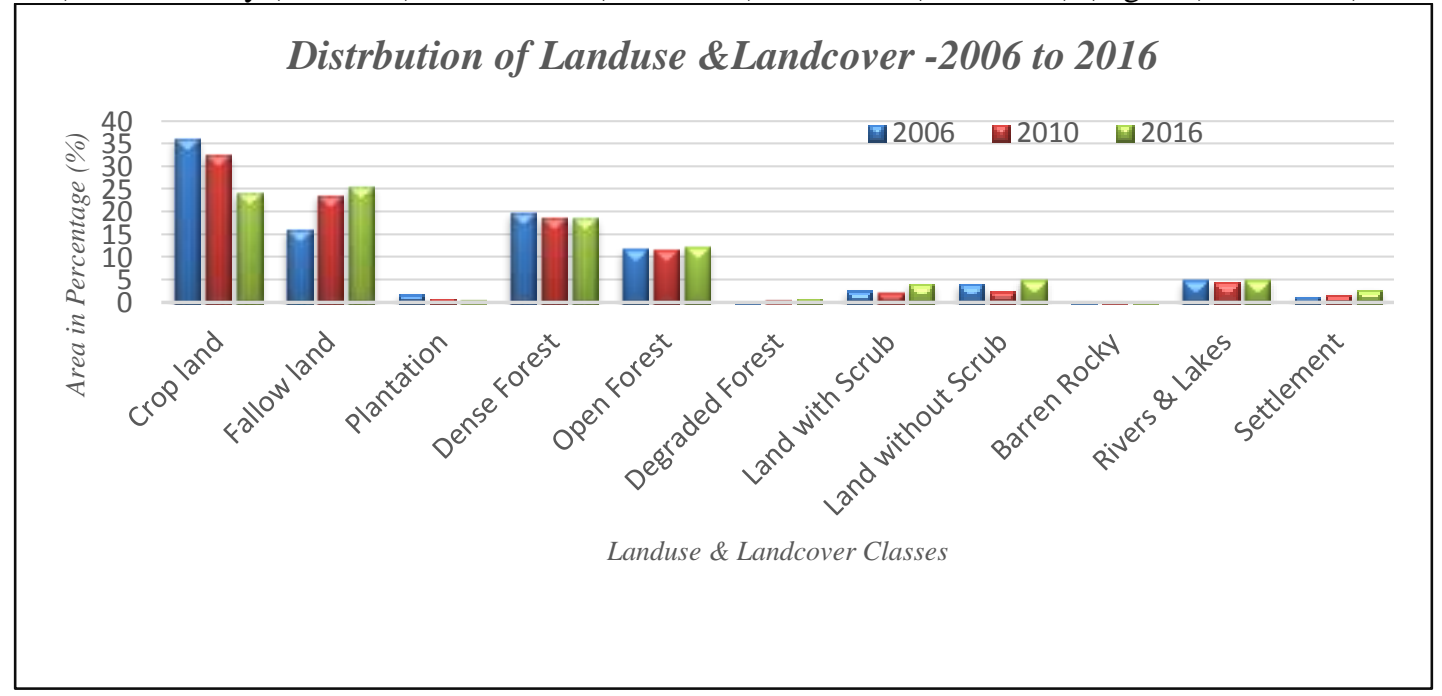

Fig 4.1:-Distribution of Land use \& Landcover-2006 to 2016

The present the study area years of 2006 is crop land $36.19 \%$ fallowing the year of 2010 is $32.63 \%$ and the years of 2016 is $24.24 \%$. The fallow land $16.14 \%$ Fallowing by the years of 2010 is $23.79 \%$ and 2016 is $25.78 \%$, plantation is the years of 2006 is $2.04 \%, 2010$ is 1.01 , and 2016 is 0.47 ,dense forest is the years of 2006 is $19.89 \%, 2010$ is $18.78 \%$ and 2016 is $18.69 \%$,open forest is the years of 2006 is $11.94 \%, 2010$ is $11.84 \%$ and 2016 is $12.40 \%$,degraded forest is the years of 2006 is $0.21 \%, 2010$ is $0.46 \%$ and 2016 is $0.92 \%$, land with scrub is the years of 2006 is $2.82 \%, 2010$ is $2.31 \%$ and 2016 is $4.23 \%$, land without scrub is the years of 2006 is $4.26 \%, 2010$ is 2.60 , and 2016 is $5.12 \%$, barren rocky is the years of 2006 is $0.04 \%, 2010$ is $0.03 \%$ and 2016 is 0.04 ,rivers\&lakes is the years of 2006 is $5.02 \%, 2010$ is 4.73 , and 2016 is $5.17 \%$ and settlement is the years of 2006 is $1.45 \%, 2010$ is $1.83 \%$, and 2016 is 2.93\%.(Fig-4.1),(Table-3.4). 
The gomukhi river basin land use and land cover changes the crop land is the years of $2006-2010$ is $-3 \%$, 2010 to $2016-8.36 \%$, and 2006 to 2016 is $-11.95 \%$ per year averages is $2.38 \%$ crop land is decreasing, the fallow land is the years of $2006-2010$ is $7.65 \%, 2010-2016$ is $9.64 \%$ and 2006 to 2016 is $19.28 \%$ the per year averages of fallow land is $1.92 \%$ increasing.

The plantation is the years of $2006-2010$ is $1.03 \%, 2010-2016$ is $0.54 \%$ and 2006 to 2016 is $1.57 \%$ the per year averages of plantation is $0.31 \%$ decreasing, dense forest is the years of $2006-2010$ is $-1.11 \%, 2010-2016$ is $-0.09 \%$ and 2006 to 2016 is $-2.40 \%$ the per year averages of dense forest is $0.23 \%$ decreasing, open forest is the years of $2006-2010$ is $-0.09 \%, 2010-2016$ is $0.56 \%$ and 2006 to 2016 is $0.47 \%$ the per year averages of open forest is 0.93 $\%$ Increasing, degraded forest is the years of $2006-2010$ is $0.24 \%, 2010-2016$ is $0.46 \%$ and 2006 to 2016 is $0.70 \%$ the per year averages of degraded forest is $0.14 \%$ Increasing, land with scrub is the years of $2006-2010$ is -0.52 $\%, 2010-2016$ is $1.93 \%$ and 2006 to 2016 is $1.41 \%$ the per year averages of land with scrub is $0.28 \%$ Increasing, land without scrub is the years of $2006-2010$ is $-1.66 \%, 2010-2016$ is $2.52 \%$ and 2006 to 2016 is $0.86 \%$ the per year averages of land without scrub is $0.17 \%$ Increasing, barren rocky is the years of $2006-2010$ is $-0.01 \%$, $2010-2016$ is $0.01 \%$ and 2006 to 2016 is $0.0 \%$ the per year averages of barren rocky is $0.0 \%$ no changes, rivers /lakes is the years of $2006-2010$ is $-0.29 \%, 2010-2016$ is $0.44 \%$ and 2006 to 2016 is $0.15 \%$ the per year averages of rivers /lakes is $0.02 \%$ Increasing, and the settlement is the years of $2006-2010$ is $0.38 \%, 2010-2016$ is $1.10 \%$ and 2006 to 2016 is $1.48 \%$ the per year averages of rivers /lakes is $0.29 \%$ Increasing.(Fig4.2),(Table-3.4).

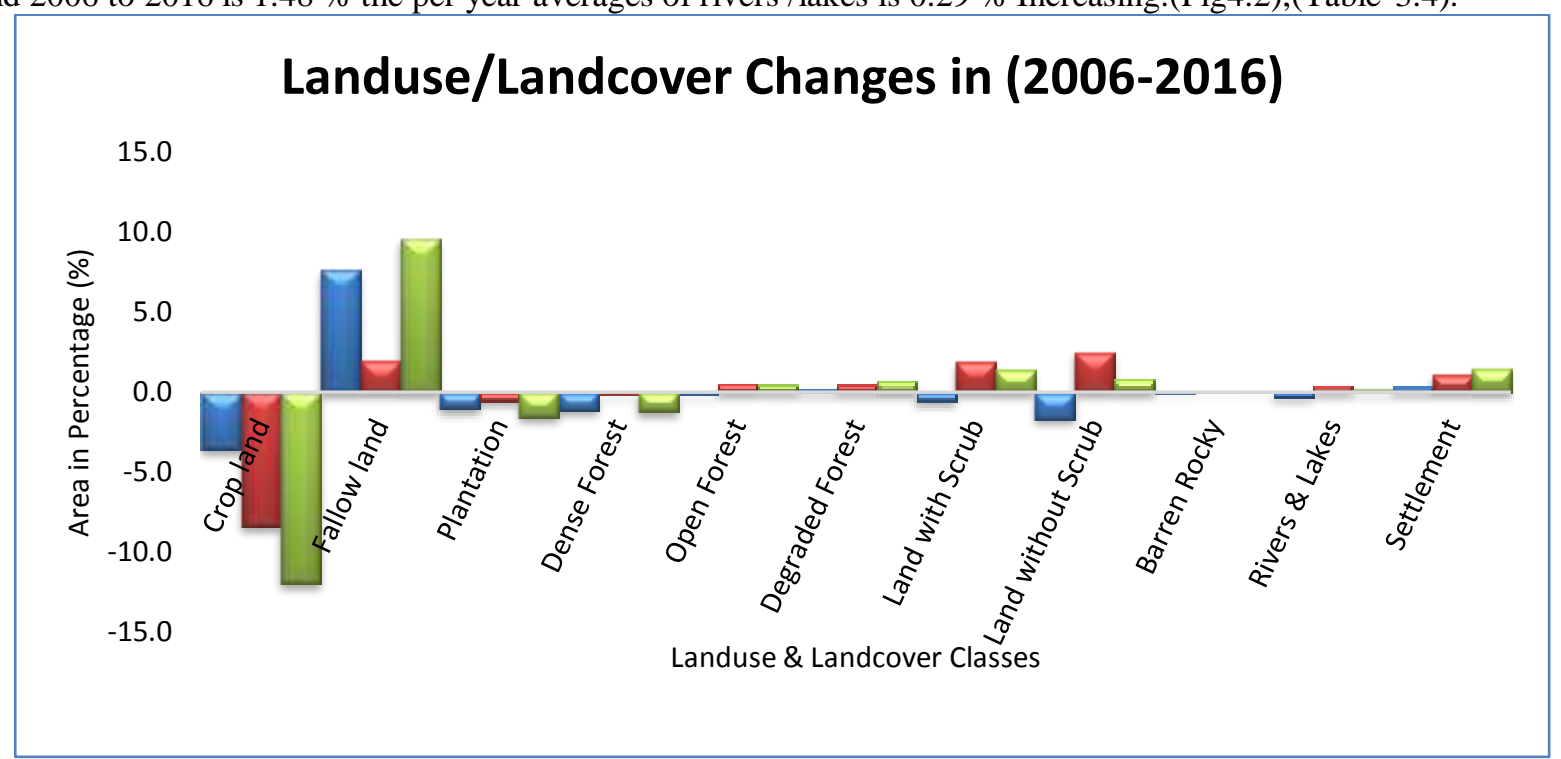

Fig- 4.2:- Land use/Land cover Changes in (2006-2016

\section{Conclusion:-}

The Gomukhi river basin concluded the land use /land cover practise and changes in the significantly 2006,2010 and 2016.The land use /land cover of crop land $2.38 \%$, plantation $0.31 \%$,dense forest $0.23 \%$, respectively per annum decreasing because of crop land and plantation more maintenance cost and not enough of water so that converting fallow land etc. Dense forest converted to open forest and degraded forest because of increasing the population so need of live hood activity most of accrued in the hills area. The fallow land $1.92 \%$, open forest $0.09 \%$, degraded forest $0.14 \%$, land with scrub $0.28 \%$, land without scrub $0.17 \%$, rivers/lakes $0.02 \%$, and settlement $0.29 \%$ respectively per annum increasing. Its fallow land and settlement continually increasing, barren rocky no changes in the study area, open forest, land with scrub, land without scrub, barren rocky and rivers/lakes are 2006 to 2010 Viz.,0.09\%,0.52\%,1.66\%,0.01\% and 0.29\% decreasing, But same classes the year of 2010 to 2016 this land use /land cover parameters is increasing. The effective watershed management conservation is based on degradation level so as to conserve and minimize the human induced impacts such as water and forest degradation. Its forest conservation step of protecting and restoring the forest would be providing incentives to the local people for guarding the new plantation. The proper watershed management should take appropriate steps to restore the degraded lands particularly soil, water, forest and agricultural land their further degradation must be prevented. 


\section{References:-}

1. Ashraf, A., 2013. Changing Hydrology of the Himalayan Watershed. Current Perspectives in Contaminant Hydrology and Water Resources Sustainability. Intech, Islamabad.

2. Bazgeera, S., Sharma, P.K., Maheya, R.K., Hundala, S.S., Sood, A., 2008. Assessment of land use changes using remote sensing and GIS and their implications on climatic variability for Balachaur watershed in Punjab, India. Desert 12, 139-147.

3. Boori, M.S., Voženı'lek, V., Choudhary, K., 2015. Land use/cover disturbance due to tourism in Jesenı'ky Mountain, Czech Republic: a remote sensing and GIS based approach. Egypt. J. Remote Sens. Space Sci. 18 (1), 17-26. http://dx.doi.org/10.1016/ j.ejrs.2014.12.002

4. Butt, A., Shabbir, R., Ahmad, S.S., Aziz, N., Nawaz, M., Shah, M.T.A., 2015. Land cover classification and change detection analysis of Rawal watershed using remote sensing data. J. Biol. Environ. Sci. 6 (1), 236-248.

5. Caruso, G., Rounsevell, M.D.A., Cojacarus, G., 2005. Exploring a spatiodynamicneighborhood-based model of residential behaviour in the Brussels peri-urban area. Int. J. Geograph. Inf. Sci. 19, 103-123.

6. Dietzel, C., Herold, M., Hemphill, J.J., Clarke, K.C., 2005. Spatialtemporal dynamics in California’s central Valley: empirical links to urban theory. Int. J. Geograph. Inf. Sci. 19, 175-195.

7. Fortin, M.J., Boots, B., Csillag, F., Remmel, T.K., 2003. On the role of spatial stochastic models in understanding landscape indices in ecology. Oikos 102, 203-212.

8. Ford-Robertson, F.C. (ed). 1971. Terminology of Forest Science, Technology Practice and Products. Society of American Foresters, Washington, DC.

9. Gajbhiye, S., Sharma, S.K., 2012. Land use and land cover change detection of Indra river watershed through remote sensing using multi-temporal satellite data. Int. J. GeomaticsGeosci. 3, 89-96.

10. HaglerBailly, 2007. Environmental baseline study of Margala and Margala north blocks. MOL Pakistan Oil and Gas Company BV, Islamabad.

11. Hu, H.B., Liu, H.Y., Hao, J.F., An, J., 2012. Analysis of land use change characteristics based on remote sensing and GIS in the Jiuxiang river watershed. Int. J. Smart Sens. Intell. Syst. 5, 811-823.

12. Iqbal, M.F., Khan, I.A., 2014. Spatiotemporal land use land cover change analysis and erosion risk mapping of Azad Jammu and Kashmir, Pakistan. Egypt. J. Remote Sens. Space Sci. 17,209-229.

13. Kearns, F.R., Kelly, N.M., Carter, J.L., Resh, V.H., 2005. A method for the use of landscape metrics in freshwater research and management. Landscape Ecol. 20, 113-125.

14. Ministry of Rural development \& NRSC (2011), Wastelands Atlas of India-2011, National Remote Sensing Centre, ISRO, Hyderabad.

15. NRSA, (2006), Manual of National Land Use Land Cover Mapping Using Multi-Temporal Satellite Data, Department of Space, Hyderabad

16. NRSA, (2007), Manual of National Wastelands Monitoring Using Multitemporal Satellite Data, Department of Space, Hyderabad.

17. NRSC (2014), Land Use / Land Cover database on 1:50,000 scale, Natural Resources Census Project, LUCMD, LRUMG, RSAA, National Remote Sensing Centre, ISRO, Hyderabad

18. Parker, D., Meretsky, V., 2004. Measuring pattern outcomes in an agent-based model of edge-effect externalities using spatial metrics. Agric. Ecosyst. Environ. 101, 233-250.

19. Rawat, J.S., Kumar, M., 2015. Monitoring land use/cover change using remote sensing and GIS techniques: a case study of Hawalbagh block, district Almora, Uttarakhand, India. Egypt. J.Remote Sens. Space Sci. 18, 77-84.

20. Rawat, J.S., Biswas, V., Kumar, M., 2013a. Changes in land use/cover using geospatial techniques: a case study of Ramnagar town area, district Nainital, Uttarakhand, India. Egypt. J. Remote Sens. Space Sci. 16, 111-117.

21. Stewart, T.J., Janssen, R., van Herwijnen, M., 2004. A genetic algorithm approach to multiobjective land use planning. Comput. Oper. Res. 31, 2293-2313.

22. Singh, P., Gupta, A., Singh, M., 2014. Hydrological inferences from watershed analysis for water resource management using remote sensing and GIS techniques. Egypt. J. Remote Sens. Space Sci. 17, 111-121.

23. Tanvir, A., Shahbaz, B., Suleri, A., 2006. Analysis of myths and realities of deforestation in northwest Pakistan: implications for forestry extension. Int. J. Agric. Biol. 8, 107-110.

24. Turner, M.G., Gardner, R.H., O’Neill, R.V., 2001. Landscape Ecology in Theory and Practice Pattern and Process. Springer- Verlag, New York.

25. UNESCO. 1973. International Classification and Mapping of Vegetation. Paris.

26. Wang, X., Zheng, D., Shen, Y., 2008. Land use change and its driving forces on the Tibetan Plateau during 19902000. Catena 72, 56-66.

27. Wani, S.P., Sreedevi, T.K., Reddy, T.S.V., Venkateswarlu, B., Prasad, C.S., 2008. Community watersheds for improved livelihoods through consortium approach in drought prone rain-fed areas. J. Hydrol. Res. Dev. 23 , 55-77. 